\title{
Avatars and Sustainability of International Political Systems
}

\author{
Utangisila Bena Osée \\ Central China Normal University, Wuhan, China \\ Email: oseebena@yahoo.com
}

How to cite this paper: Osée, U. B. (2019). Avatars and Sustainability of International Political Systems. Open Journal of Political Science, 9, 243-252.

https://doi.org/10.4236/ojps.2019.92013

Received: January 8, 2019

Accepted: January 26, 2019

Published: January 29, 2019

Copyright (c) 2019 by author(s) and Scientific Research Publishing Inc. This work is licensed under the Creative Commons Attribution International License (CC BY 4.0).

http://creativecommons.org/licenses/by/4.0/

\section{cc) (i) Open Access}

\begin{abstract}
All the facts mentioned in this article lead this study to consider that political borders established after the Second World War and managed by the East-west bipolarity have changed. But that does not change the nature and practice of international politics, hence does the idea of sustainability of international political systems. The situation of the current international system, the ongoing mutations do not lead to the end of the conflicting relations between the main centers of power. As conflicts of interest are unwaveringly attached to international politics or to the short-term policy, the new system in gestation will therefore not be fundamentally different from the above.
\end{abstract}

\section{Keywords}

Avatar, Sustainability, System

\section{Introduction}

This article briefly explains the Avatars and constants of international political systems. To do this, three key points are devoted to it is analysis: disintegration phenomenon of the system, the transformation of contemporary bipolar system, and the structuring of international system. The main purpose of this research is to make it known that each international political system is a reality in which this reality can be located in two ways in time and space. This means that any international system is dynamic and it is admitted to the law of change. The changes can lead a system either to its disintegration or to the redistribution of roles, or still to the mutation or restructuring. Since the end of the Second World War, international relations have undergone major transformations, especially 
since the collapse of the Soviet empire took place in the context of globalization. The destruction of the Iron Curtain, the enlargement of the European Union (EU), the rise in strength of new poles of political and economic power Asia, in the forefront of which China and India, the very rapid expansion of markets for goods and services Spurred both by the culmination of the Uruguay round negotiations and by technical innovations in the communications and information sectors, the increasing control of the business community on the global economy, the disruption Politico-strategic sequences as of September 11, 2001 are aspects of these changes. States are now intertwined in networks of close interdependence, and individuals, as well as social movements, interact at the global level through these structural and political developments.

\section{Significance of the Study}

The significant of this study is to understand the different changes the world has undergone since the end of the Second World War between the two superpowers the US and the USSR. Some peoples until now still making a doubt about the world changes, some still thinking that we still in the bipolar world, some of them in the multipolar world. Today we are in a world where there are several centers of power, several very large powers as opposed to the bipolar world of the Cold War and the unipolar world after the Cold War. As a result of this opposition, we must talk about a multipolar world.

\section{Definition of Concepts}

This point deserves to define some basic concepts to avoid some confusion in their uses. These are following concepts: Avatar, sustainability, system, political system, and international politics.

\subsection{Avatar}

The virtual identity is also called "Avatar", a word of Sanskrit origin. In Hindu mythology, an avatar was the embodiment of the Vishnu God.

http://www.cnrtl.fr/definition/avatar

The word avatar in this article means changes or transformation.

\subsection{Sustainability}

Sustainability is defined as the continuity of benefits (such as control of disease progression or a level of service attained) that are proposed during the implementation of a program, after an initial investment has been made (Blanchet \& Boggs, 2012). The notion of sustainability refers to what lasts in the long run, the continuity of a process and its existence in the long term. Example of the process of the Second World War pitted the US-USSR, we can understand that this war had duration and after the end of the second war the two great Powers are in existence or continuity. 


\subsection{System}

A system can be defined as progressing towards sustainability when the quality of the system is maintained or improves over time. However, the quality of a system remains a subjective value (Liverman \& Merideth, 1988; Mitchell \& McDonald, 1995). It is therefore essential to understand how individuals define the quality of a system and how they prioritize it.

\subsection{Political System}

Political system is an organized ensemble: political Institutions (State apparatus, government agencies, ministries); political actors (individuals, parties, trade unions, non-governmental organizations); political norms and beliefs (ideologies, doctrines, laws, rules); political relations (Government-governed, state-society, international relations). https://e-edu.nbu.bg/pluginfile.php

\subsection{International Policy}

The concept of international politics is polysemy, but generally covers two realities. In the first stage it represents the power relations between the state actors beyond the borders of at least one state. In a second step, it refers to academic discipline that is interested in international issues (Paquin, 2012).

The concept of international policy must be differentiated from that of global politics, since the latter includes in analysis the international public and private actors' also known as transnational actors. These actors can be multinationals, non-governmental organizations (NGOs) such as Greenpeace or Doctors Without borders or even terrorist movements like Al Qaida (Smith, Owen, \& Baylis, 2011). Finally, international policy is different from foreign policy which, according to Marcel Merle, is "the part of state activity that is turned to" outside (Merle, 1984). In this case it is an international public policy.

\section{Phenomenon of Disintegration of the System}

Let us take the example of the contemporary international system after the Second World War. The post-World War II system was described as bipolarity, but in reality it quickly passed from bipolarity to multipolarity. If at the release of World War II, the system was under the control of only two major antagonistic powers by the game of military alliances and ideological solidarity and thus bipolar, this lasted only some five years.

The bipolar was structured by the rivalries between the Communists (USSR) and the Capitalists (USA), thus the USA and USSR regarded as the only two world powers. It should be noted that the US and the USSR embody two opposing and influential models in 1945. Thus in 1945 the USA and the USSR appeared as the two "great" winners of Nazism. But they represent two opposing political, economic and social models.

These models can be presented by this table. 


\begin{tabular}{|c|c|c|}
\hline & USA & USSR \\
\hline Policies & $\begin{array}{l}\text { Democracy guaranteeing liberties and } \\
\text { pluralistic (several Parties) }\end{array}$ & $\begin{array}{l}\text { Official democracy, but in reality a dictatorship, that of Stalin, } \\
\text { which reigns over a single party, thus communism. }\end{array}$ \\
\hline $\begin{array}{l}\text { Economic } \\
\text { and social }\end{array}$ & $\begin{array}{l}\text { Capitalist economy based on private property and the } \\
\text { freedom to undertake, and valuing individual success. }\end{array}$ & $\begin{array}{l}\text { Communist economy based on collective ownership and } \\
\text { planning of the economy by the state. }\end{array}$ \\
\hline $\begin{array}{l}\text { How they } \\
\text { fascinate? }\end{array}$ & $\begin{array}{l}\text { The standard of living is the highest in the world, giving birth } \\
\text { to the American way of life based on consumer society. }\end{array}$ & $\begin{array}{l}\text { Ideal of social equality, of a society without rich or poor, } \\
\text { where the State ensures the welfare of the population. } \\
\text { Propaganda also suggests the success of this society. }\end{array}$ \\
\hline
\end{tabular}

The bipolar world was based on the symmetrical comparability of the economic and military-strategic parity potential of the two warring American and Soviet sides. At the same time, no other country affiliated with a particular camp had the cumulative power to compare itself with that of Moscow or Washington. As a result, there were two hegemons on a global scale, each surrounded by a constellation of allied countries. In this model, officially recognized national sovereignty has gradually lost its weight. First, the countries associated with a hegemon depended on the policies of this pole. As a result, these countries were not independent and regional conflicts (generally developed in the third World regions) quickly evolved into a confrontation between two superpowers seeking to redistribute the balance of the global influence on the "disputed territories". This explains the conflicts in Korea, Vietnam, Angola, Afghanistan, etc. In the bipolar world there was also a third force the Movement of Non-aligned. It consisted of a few third world countries that refused to make an unequivocal choice in favor of capitalism or socialism and preferred to maneuver between the global antagonistic interests of the United States and the USSR. To some extent, some were successful, but the possibility of non-alignment implied the existence of two poles, which at varying degrees were balancing. Moreover, these "non-aligned Countries" could not in any way create a "third pole" because of the main parameters of the superpowers, the fragmentation and weakness of the members of the Movement of Non-Aligned Countries, and the lack of a platform Common socio-economic. The world was divided into a capitalist West (the First world), a socialist Orient (the Second world) and the "Rest" (the Third World). Moreover, "all others" represented in every sense the world periphery where the interests of superpowers sometimes appeared. After the collapse of one of the two poles (the Soviet Union collapsed in 1991), the bipolar system also collapsed. This created the prerequisites for the emergence of an alternative world order. Many analysts and intelligence experts have rightly spoken of "the end of the Yalta system". Although acknowledging sovereignty, the peace of Yalta was de facto built on the principle of the equilibrium of the two symmetrical and relatively equal hegemons. With the departure of one of the hegemons of the historical scene, the whole system ceased to exist. The time for a unipolar world order or "unipolar moment" has arrived. As some experts claim. The multipolar world begins from the years the two superpowers no longer succeed in establishing or restoring order. From the mid-1970s onwards, the world became multipolar and settled what P. Milza called "a New World disorder" (Milza, 
1983). The multipolar world is not a recent creation but since 70 with the assertion of new Poles. It must therefore be stressed that the years 70 were a major turning point which was not diminished by the events of 1989-1991. Jean Baptiste Duroselle and André Kaspi (Duroselle \& Kaspi, 1945). Rather value the events of the years 90: "After the demise of the Soviet Union, everything changes" because "alone, the United States retains the status of political and diplomatic superpower, economic and technological, military and cultural." This is also the opinion of Eric HobsBawm. At the end of the chapter he devoted to the Cold War in a book published in 1999 (HobsBawm, 1914-1991). He writes "It is historical moments that even contemporaries can recognize that they mark the end of an era." The beginning of the years 90 was clearly a moment of this type.

It should be noted, very soon after the hot war, that the advent of new players in the endowment of nuclear Weapons, which was hitherto the prerogative of the only two powers (USA and the USSR in the aftermath), occurred on the international political scene. The new nuclear players refuse with the exception of the Great Britain, which remains dependent on the USA. France for its part has left NATO command for the benefit of its own defense force; And China has forged its own self-tapping force. Even if they are smaller, India and Israel have refused to sign the Treaty on the Non-Proliferation of Nuclear Weapons.

Under these conditions, even if the margin of superiority of the US and the USSR in the field of nuclear weapons remains unbeatable, their monopoly is nevertheless broken. As a result, the deterrence strategy that formed the basis of the bipolar system at the outset could no longer function satisfactorily and it was necessary to construct new hypotheses around a triangular configuration. But the end of bipolarity is not only the result of the expansion of the nuclear club.

We believe it is necessary to add the doubt that the nuclear weapon itself produces as regards its effective use in international relations. Indeed, other non-nuclear players have been convinced that the use of atomic weapons is highly unlikely because of the devastating effects on all players indiscriminately including holders themselves. It is more of a weapon of diplomatic blackmail than of strategic action. Under these conditions, the alleged protection provided by the two major Powers does not merit unconditional alignment.

It should be noted that before 1950, the two blocs that constituted the international system were very homogeneous and coherent confrontational fronts. Thereafter, the two coalitions no longer exhibited the same solidarity or consistency. Indeed:

* On the west side of the bloc, the crisis in the bloc is manifested by the loosening or even disappearance of regional defense pacts such as A.N.U.Z.S. (for the Pacific), SEATO (Southeast Asia), Cento (Middle East). Moreover, OAS fails to master the oppositions and claims against the USA. France defected to NATO economically; EEC became the rival of American interests in Europe and elsewhere.

* On the eastern side, the USSR strives to control the initiatives of the popular 
democracies and to prevent deviationism as necessary by force (example: military intervention in Czechoslovakia in 1968). But schism divided the communist bloc and the USSR failed to prevent it. In central Europe, Albania has followed Chinese trend and has broken relations with the Warsaw pacts and COMECON. There is also resistance of Romania which has opted for national communism and finally displays an independent diplomacy. Let say that all these facts have greatly reduced Moscow's influence on the actors in its bloc and therefore on the system. All these considerations lead us to speak now of influences rather than real blocks.

It should be noted that the multipolar world differs from the classical Westphalian system by the fact that it does not recognize a separate, legally and formally sovereign, nation-state to have the status of a full-fledged pole. This means that the number of Poles in a multipolar world should be significantly less than the number of recognized (and therefore unrecognized) nation states. The vast majority of these states are not in a position today to secure their own security or their own prosperity in the face of a theoretically possible conflict with the current hegemon (the United States). Therefore they are politically and economically dependent on an outside authority. By being dependent, they cannot be the centers of a truly independent and sovereign will on the global issues of the world order (Source

http://katehon.com/1290-multipolarity-the-definition-and-the-differentiation-b etween-its-meanings.html). Multipolarity does not work with the situation as it exists de jure but rather de facto and proceeds from the statement of fundamental inequality between nation states in the modern and empirically modifiable model of the world. Moreover, the structure of this inequality is that the secondary and tertiary powers are not in a position to defend their sovereignty, in any transitional bloc configuration, in the face of a possible external challenge by the hegemonic power. This means that sovereignty is today a legal fiction. It is worth pointing out, the multipolar world is not a bipolar world (as we experienced in the second half of the twentieth century), because in today's world there is no power capable of withstanding the strategic power of the United States and NATO countries And there is no general and coherent ideology capable of uniting a large part of humanity in a harsh opposition to the ideology of liberal democracy, capitalism and "human rights", on which the United States is based a new Unique hegemon. Neither modern Russia nor China, nor India nor any other state can claim to be a second pole under these conditions. The recovery of bipolarity is impossible for ideological reasons (the end of the popular Call of Marxism) and military-technical reasons. As for the latter, the United States and NATO have taken the lead over the last 30 years, so that symmetrical competition with them in the military, strategic, economic and technical fields is not possible for any country.

(http://lesakerfrancophone.fr/multipolarite-definition-et-comparaison-de-ses-di fferents-sens) 


\section{Transformation of the Contemporary Bipolar System}

If the cracks and some disintegration at the level of each block were born, the decline of the Eastern bloc led to a real implosion in the years 1989 to the point of removing to the notion of bipolarity of the international system its popular sense that diplomatic-strategic.

Indeed, the landmarks of the collapse of the Eastern Bloc can be established around:

$>$ Liberalization of popular democracies and the sinking of communist ideology;

> The fall of the Berlin Wall in November 1989, with its German unification;

$>$ The dissolution of the Warsaw Pact and the CMECON.

The Western credo is now being imposed in the Eastern zone with its three fundamental principles:

- The rights of peoples and nations to self-determination;

- Liberal economy;

- Liberal democracy and human rights.

The breakup of Central and Eastern Europe has led to the emergence of new solidarity. Example: The Baltic states are turning to the Nordic countries and the European Union, the new States of Central Asia and the Caucasus are forging with Iraq and Turkey, Central European States, Russia (The admission of Russia to NATO seems still difficult to imagine but let time to time) and Ukraine are interested in their insertion In the Council of Europe and the European Union.

In addition, almost all States of the former communist bloc were admitted to the international financial and commercial institutions of the United Nations for which they were reluctant (IMF, IBRD, WTO, GATT, etc.). China has long been prevented from becoming a WTO member since November 2001.

In short, we can observe that in this movement of the decomposition of the Eastern bloc, Europe is regaining its continental dimension and its historical and geocultural base. Institutions like the CSCE are indicative of an evolution that does not deceive!

Outside Europe, the change of the bipolar system is noted by three major facts:

- The cessation of many regional conflicts that were fueled by East-West or better Soviet-American rivalry, mainly in third World (e.g. Latin America, especially central, southern Africa, Cambodia, Afghanistan...);

- The gradual rehabilitation of the United Nations in its role as an international peace policeman. The right of veto is no longer abused or brutally used to defeat decisions on the maintenance of peace and international security where it is threatened.

- The embranglement of dictatorial political regimes that reigned in the shadow of conflict in Africa, Asia and Latin America. Hence the wind of democratization that accompanied the dislocation of USSR known as perestroika. Example: Asia (South Korea, Thailand, Burma, Beijing Spring of 1989, etc.), Africa (democratic transition process completed in some cases or ongoing everywhere). 
All the facts mentioned-above lead to consider that the political borders established after the Second World War and managed by the East-West bipolarity have changed. But that does not change the nature and practice of international politics.

\section{Structuring of the International System}

When a political system is disrupted in its operation, two solutions are available: or it operates adaptive reform. For disturbances (defection of limbs, loss of power by a limb, etc.) will not alter the essence of international politics which has its anarchic nature despite the existence of hegemonic relations or power hierarchies.

To return to the situation of the current international system, the current mutations do not lead to the end of the conflicting relations between the main centers of power (example: USA, France, Russia, and China). As conflicts of interest are unwaveringly attached to international politics or to short-term policy, the new system in gestation will therefore not be fundamentally different from the above.

The essential traits will still be present namely:

- A concerted and comprehensive international response to common issues in particular: the promotion of peace and security, the promotion of development, the reduction of poverty and its corollaries, the protection of the environment control of The population explosion, the promotion and respect for human rights and democracy;

- A community of destiny that must unite individuals and peoples in a world whose components are in a position of interdependence, gradually leading to the erosion of national sovereignty;

- The political will of the underdeveloped countries.

There is no determinism that controls the failure of this project. The example of the Asian Dragons demonstrates that NOEI is not as utopian as we think. The southern ideology can lead far if the victims of the old and the current world order actually perform their will for internal and international change.

\section{Discussion}

We can remember that in 1945 the two largest world powers the United States and the USSR are quickly opposed to their ideologies. The United States is a capitalist and democratic country while the USSR is a communist. Around the years 1947, Truman criticized the USSR's willingness to expand, imposing communist dictatorships in Eastern European countries. To help Europe rebuild, in 1947, the United States offers economic aid to European countries: the Marshall plan. This plan is accepted by western European countries only. The USSR criticizes Marshall Plan and accuses the United States of wanting to impose their economic domination on the world. In 1949, the USSR was endowed with atomic a weapon that is why the two superpowers do not clash directly. 
They are indirectly opposed to peripheral conflicts such as the Korean War (1950-1953). During the Cold War, an intense propaganda is used by each of the two blocks to show its superiority and denigrate the opposing camp. The cinema, the posters, the comics are propaganda tools. The multipolar world is a radical alternative to the unipolar world (which actually exists in the current situation) by insisting on the presence of a few global and independent strategic decision-making centers worldwide. These centers should be sufficiently equipped and financially and physically independent to be able to defend their sovereignty in the face of a direct invasion by a potential enemy on the material plane and the most powerful force in the world today should be understood as this threat. This requirement is reduced to being able to withstand the financial, military and strategic hegemony of the United States and NATO countries. These decision-making centers must not accept the universalism of Western standards, norms and values (democracy, liberalism, free market, parliamentarianism, human rights, individualism, etc.) and may be totally independent of the spiritual hegemony of the West. The multipolar world does not imply a return to the bipolar system because today there is not a single strategic or ideological force capable of withstanding the material and spiritual hegemony of the modern west and its leader, the United States. There must be more than two poles in a multipolar world. The multipolar world does not seriously consider the sovereignty of existing nation states, which is declared only at a purely legal level and is not confirmed by the presence of a power, a strategic, economic and political potential Sufficient. In the 21st century, it is no longer enough to be a nation-state to be a sovereign entity. In such circumstances, real sovereignty can only be achieved by a combination and a coalition of states.

\section{Conclusion}

It should be concluded by saying that the deterrence strategy which formed the basis of the bipolar system at the outset could no longer function satisfactorily and it was necessary to construct new assumptions around a Triangular configuration. But the end of bipolarity is not only the result of the expansion of the nuclear club. In reality the so-called protection provided by the two great Powers does not deserve unconditional alignment. Finally, the two coalitions no longer exhibited the same solidarity or consistency. In the situation of the current international system, the ongoing mutations do not lead to the end of the conflicting relations between the main centers of power. As conflicts of interest are unwaveringly attached to international politics or to the short-term policy, the new system in gestation will therefore not be fundamentally different from the above.

\section{Conflicts of Interest}

The authors declare no conflicts of interest regarding the publication of this paper. 


\section{References}

Blanchet, K., \& Boggs, D. (2012). The Process of Analyzing Sustainability: Example of Functional Rehabilitation, December.

http://www.hiproweb.org/uploads/tx_hidrtdocs/GM08Perennite.pdf

Duroselle, J.-B., \& Kaspi, A. (1945). History of International Relations (16th ed.). Armand Colin, "Classic", 2002, 663 p.

HobsBawm, E.-J. (1914-1991). The Age of Extremes. The Short Twentieth Century (p. 810). Paris: Éditions Complexe.

http://www.cnrtl.fr/definition/avatar

http://www.hiproweb.org/uploads/tx_hiditdocs/GM08Perennité.pdf

https://e-edu.nbu.bg/pluginfile.php/.../0/Le_systeme_politique_Desi.pdf

Liverman, D. M., Hanson, M. E., Brown, B. J., \& Merideth, R. W. (1988). Global Sustainability toward Measurement. Environmental Management, 12, 133-143.

https://doi.org/10.1007/BF01873382

Merle, M. (1984). Foreign Policy. Paris: Press Universities of French.

Milza, P. (1983). The New World Disorder. Paris: Flammarion.

Mitchell, G., May, A., \& McDonald, A. (1995). Picabue-A Methodological Framework for the Development of Indicators of Sustainable Development. International Journal of Sustainable Development and World Ecology, 2, 104-123.

https://doi.org/10.1080/13504509509469893

Paquin, S. (2012). The Theories of International Political Economy. Paris: Presses of Politics Science.

Smith, S., Owen, P., \& Baylis, J. (2011). Introduction. In J. Baylis, S. Smith, \& P. Owen (Eds.), The Globalization of World Politics: An Introduction to International Relations (pp. 1-13). Oxford: Oxford University Press. 